\title{
CFD Simulation for a Road Vehicle Cabin
}

\author{
Jalal M. Jalil and Haider Qassim Alwan \\ Educational Technology Department \\ University of Technology, Baghdad, Iraq \\ jalalmjalil@yahoo.com
}

\begin{abstract}
A numerical study of a two-dimensional, turbulent, recirculating flow within a passenger car cabin is presented. The study is based on the solution of the elliptic partial differential equations representing conservation of mass, momentum, temperature, turbulence energy and its dissipation rate in finite volume form. Algebraic expressions for the turbulent viscosity and diffusion coefficients are calculated using the two-equation $\operatorname{model}(\mathrm{k}-\varepsilon)$. Different parameters are considered to illustrate their influences on the flow filed and temperature distribution inside car cabin. These parameters include number and location of the air conditioning systems inlets inside car cabin, different air temperatures at the inlets, different air velocities at the inlets, different solar intensity during day-time for a certain day of the year, different diffuse solar radiation (variation in the kind of car glass).

Generally, the results indicate some of negative effects such as development of zones of low air circulation. Also it is found that the number of inlets inside car cabin play an important role in determining car air conditioning system efficiency. Moreover, the air temperature and velocity at inlets play an important role in determining cabin climate. The results are used to enhance the understating of the airflow fields within a road vehicle passenger cabin.
\end{abstract}

Keywords: CFD, Air Conditioning, Automobile

\section{Introduction}

Simulation of passenger compartment climatic conditions is becoming increasingly important as a complement to wind-tunnel and field testing to help achieve improved thermal comfort while reducing vehicle development time and cost. Thermal analysis of a passenger compartment involves not only geometric complexity but also strong interactions between airflow and the three modes of heat transfer, namely, heat conduction, convection, and thermal radiation. In addition, the need to reduce heat loads that captivate 
the passenger compartments has become an important issue in the early stage of vehicle design. Since air conditioning system capacity cannot continue to increase at the rate glass area is increasing, it has become necessary to develop tools that can predict the impact of various designs on passenger thermal comfort early in the design process.

Improving air conditioning performance and occupant thermal comfort requires an understanding of the fluid motion prevailing in the compartment for any given ventilation setting and passenger loading. The recent advancement in Computational Fluid Dynamics (CFD) and experimental diagnostic techniques has encouraged a number of researchers to examine the climatic environment within vehicles. These studies range from those reporting general flow observations to those attempting to model the prevailing environment within the compartment and recommending optimum climatic conditions and modifications. Computational fluid dynamics procedures have been applied in various studies on the important components of a HVAC (Heating- Ventilation- AirConditioning) system, ${ }^{[1-3]}$. Previously Taeyoung Han ${ }^{[4]}$ performed numerical simulations of a two-dimensional, and a three-dimensional airflow in a passenger compartment. In a study by Alexandrov et al ${ }^{[5]}$, the authors used CFD to evaluate the effect of four HVAC design parameters on passenger thermal comfort in a simplified passenger compartment. They found that the location of the vents, and the air flow rate, were the most important parameters which influenced the thermal comfort of the passengers. Moreover, the position of the outlet in the rear of the car was found to play a significant role in rear passenger thermal comfort.

In this paper, the mathematical analysis of the Partial Differential Equations (PDE's) that describe the flow of fluid in turbulent fields is presented. These equations are based on the conservation of mass and momentum. To demonstrate the effect of turbulence on the flow, a turbulence model which involves the solution of two transport equations for the turbulent kinetic energy, $(\mathrm{k})$, and the dissipation rate of turbulent kinetic energy, $(\varepsilon)$, will be described. To solve the conservative equations of the fluid flow a Finite Volume Method (FVM) is used. The (PDE's) will be presented in Cartesian coordinate system (i.e., $\mathrm{x}, \mathrm{y}$ ). The flow is assumed to be steady and incompressible with constant properties. 


\section{The Problem Description}

This study is focused on the fluid flow and heat balanced within car cabin. Figure 1 depicts the heat transfer modes taken into consideration. Namely, solar radiation $\left(\mathrm{I}_{\mathrm{t}}\right)$ and conduction through the wall $\left(\mathrm{Q}_{\mathrm{SRF}}\right)$.

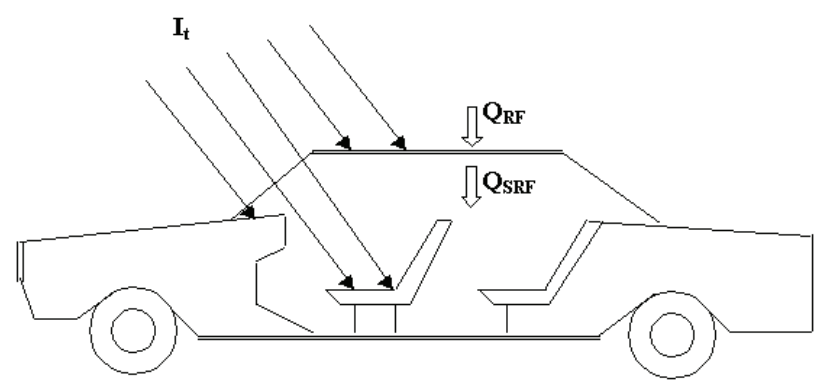

Fig. 1. Heat absorbed by the passenger compartment.

The roof absorbs solar radiation. The surface temperature of this wall rises higher than the outside air temperature because of heat absorption. This wall has both thermal capacity and resistance to heat flow. The temperature will actually vary continuously through the wall, as indicated in Fig. 2.

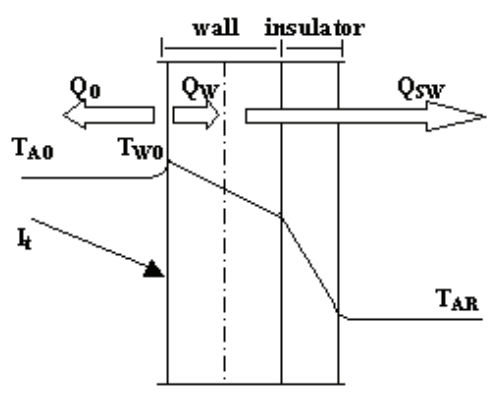

Fig. 2. Heat balance for a sunlit wall.

However, this wall is very thin (less than $0.01 \mathrm{~m}$ in thickness). The insulator is assumed to have no thermal capacity and to have lumped resistance. 
The total heat permission through glass is expressed as the sum of the solar radiation transmitted through the glass and the inward heat flow by convection from the inner glass surface, as shown in Fig. 3

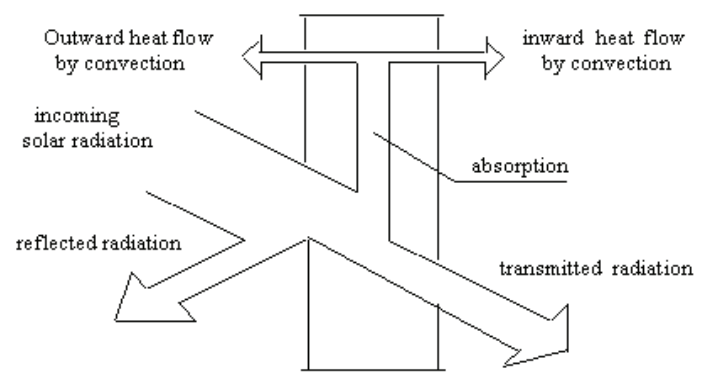

Fig. 3. Heat balance for sunlit glazing material.

The complex turbulent airflow pattern is numerically investigated for three different inlet settings. Two inlets, three inlets and four inlets are examined for three different inlet velocities. Furthermore, the behavior of temperature distribution in this cabin was computed. Also, the transient heat transfer problem on the boundary of the present car cabin was analyzed.

\section{The Governing Equations}

The basic equations, which describe the flow of fluid and temperature distribution, are the continuity equation, the Navier-Stokes equation and the equation of temperature. These equations describing twodimensional, turbulent and incompressible take the following forms for steady flow ${ }^{[6]}$.

\section{i- Continuity Equation (Mass Conservation)}

$$
\frac{\partial(\rho \mathrm{u})}{\partial \mathrm{x}}+\frac{\partial(\rho \mathrm{v})}{\partial \mathrm{y}}=0
$$

\section{ii- Momentum Equation (Navier-Stokes Equation)}

u-momentum (x-direction)

$$
\frac{\partial}{\partial \mathbf{x}}(\rho \mathrm{uu})+\frac{\partial}{\partial \mathbf{x}}(\rho \mathrm{uv})=-\frac{\partial \mathrm{p}}{\partial \mathrm{x}}+\frac{\partial}{\partial \mathbf{x}}\left(\mu_{\text {eff }} \frac{\partial \mathrm{u}}{\partial \mathrm{x}}\right)+\frac{\partial}{\partial \mathrm{y}}\left(\mu_{\text {eff }} \frac{\partial \mathrm{u}}{\partial \mathrm{y}}\right)+\frac{\partial}{\partial \mathrm{x}}\left(\mu_{\mathrm{eff}} \frac{\partial \mathrm{u}}{\partial \mathrm{x}}\right)+\frac{\partial}{\partial \mathrm{y}}\left(\mu_{\text {eff }} \frac{\partial \mathrm{v}}{\partial \mathrm{x}}\right)
$$


v-momentum (y-direction)

$$
\frac{\partial}{\partial \mathrm{x}}(\rho \mathrm{uv})+\frac{\partial}{\partial \mathrm{y}}(\rho \mathrm{vv})=-\frac{\partial \mathrm{p}}{\partial \mathrm{y}}+\frac{\partial}{\partial \mathrm{x}}\left(\mu_{\mathrm{eff}} \frac{\partial \mathrm{v}}{\partial \mathrm{x}}\right)+\frac{\partial}{\partial \mathrm{y}}\left(\mu_{\text {eff }} \frac{\partial \mathrm{v}}{\partial \mathrm{y}}\right)+\frac{\partial}{\partial \mathrm{x}}\left(\mu_{\text {eff }} \frac{\partial \mathrm{u}}{\partial \mathrm{y}}\right)+\frac{\partial}{\partial \mathrm{y}}\left(\mu_{\mathrm{eff}} \frac{\partial \mathrm{v}}{\partial \mathrm{y}}\right)
$$

\section{iii-Temperature Equation}

$$
\frac{\partial}{\partial \mathrm{x}}(\rho \mathrm{uT})+\frac{\partial}{\partial \mathrm{y}}(\rho \mathrm{vT})=\frac{\partial}{\partial \mathrm{x}} \Gamma_{\text {eff }}\left(\frac{\partial \mathrm{T}}{\partial \mathrm{x}}\right)+\frac{\partial}{\partial \mathrm{y}} \Gamma_{\text {eff }}\left(\frac{\partial \mathrm{T}}{\partial \mathrm{y}}\right)+\mathrm{S}_{\mathrm{T}}
$$

\section{The (k - $\varepsilon$ ) Model (Two-Equations Model)}

One of the most widely used turbulence models is the two-equation model of kinetic energy, $\mathrm{k}$, and its dissipation rate $\varepsilon$.This model has been applied by most investigators who studied the numerical solution of airflow in rooms ${ }^{[7,8]}$. It is used in the present work, as it is capable of handling complex room air movements in less time than other complicated modes ${ }^{[9]}$, Moreover, it is found to have sufficient accuracy for practical purposes. The turbulence according to Launder and Spalding ${ }^{[10]}$ is assumed to be characterized by it's kinetic energy, $\mathrm{k}$, and dissipation rate, $\varepsilon$, this model relates the turbulent viscosity to the local values of $\rho, \mathrm{k}$ and $\varepsilon$ by the expression:

$$
\mu_{\mathrm{t}}=\rho \mathrm{C}_{\mu} \mathrm{k}^{2} / \varepsilon
$$

Where $\mathrm{C}_{\mu}$ is an empirical "constant" value for high Reynolds number flows. The turbulence parameters $\mathrm{k}$ and $\varepsilon$ are derived from their respective transport equations. The modeled forms of these equations for steady flows have been given by Launder and Spalding ${ }^{[10]}$ as follows:

Turbulence Energy (k)

$$
\frac{\partial}{\partial x}(\rho u k)+\frac{\partial}{\partial y}(\rho v k)=\frac{\partial}{\partial x}\left(\Gamma_{k} \frac{\partial k}{\partial x}\right)+\frac{\partial}{\partial y}\left(\Gamma_{k} \frac{\partial k}{\partial y}\right)+\mu_{t}\left(2\left[\left(\frac{\partial u}{\partial x}\right)^{2}+\left(\frac{\partial v}{\partial y}\right)^{2}\right]+\left(\frac{\partial u}{\partial y}+\frac{\partial v}{\partial x}\right)^{2}\right)-\rho \varepsilon
$$

\section{Dissipation Rate $(\varepsilon)$}

$$
\frac{\partial}{\partial x}(\rho u \varepsilon)+\frac{\partial}{\partial y}(\rho v \varepsilon)=\frac{\partial}{\partial x}\left(\Gamma_{\varepsilon} \frac{\partial \varepsilon}{\partial x}\right)+\frac{\partial}{\partial y}\left(\Gamma_{\varepsilon} \frac{\partial \varepsilon}{\partial y}\right)+C_{1 \varepsilon} \frac{\varepsilon}{k} \mu_{t}\left\{2\left[\left(\frac{\partial \mathrm{u}}{\partial \mathrm{x}}\right)^{2}+\left(\frac{\partial \mathrm{v}}{\partial \mathrm{y}}\right)^{2}\right]+\left(\frac{\partial \mathrm{u}}{\partial \mathrm{y}}+\frac{\partial \mathrm{v}}{\partial \mathrm{x}}\right)^{2}\right\}-\mathrm{C}_{2 \varepsilon} \rho \frac{\varepsilon^{2}}{\mathrm{k}}
$$




\section{Boundary Conditions}

The boundary conditions for problem under consideration can be described for turbulent flow as follows:

\subsection{Inlet Boundary Condition}

Uniform distribution is used over the inlet boundary of the longitudinal velocity $\left(v_{\text {in }}\right)$ or tangential velocity $\left(u_{i n}\right)$, temperature $\left(T_{i n}\right)$, kinetic energy of the turbulent $\left(\mathrm{k}_{\text {in }}\right)$ and the energy dissipation rate $(\varepsilon)$, other velocity component (normal velocity) are taken as zero at inlet. The kinetic energy in turbulence is calculated using:

$\mathrm{k}_{\text {in }}=1.5 \mathrm{I}_{\mathrm{u}}^{2} \mathrm{u}_{\text {in }}^{2}$

Where $I_{u}$ is the turbulence intensity of the u-component of velocity at the inlet. If no information is available at all from measurement or previous related work, the value of $I_{u}$ is typically considered to be between $1-6 \%$. The dissipation rate is obtained from Awbi ${ }^{[11]}$.

$\varepsilon_{\text {in }}=\mathrm{k}_{\text {in }}{ }^{1.5} / \lambda \mathrm{H}$

Where $\mathrm{H}$ is the height of the enclosure or the square root of the cross sectional area of the enclosure, $\lambda$ is a constant as 0.005 .

\subsection{Outlet Boundary Conditions}

The longitudinal component, $\mathrm{u}_{\mathrm{o}}$ is derived from the continuity equation, i.e. :

$\mathrm{u}_{\text {out }}=\mathrm{u}_{\text {in }} \mathrm{A}_{\text {in }} / \mathrm{A}_{\text {out }}$

Where subscript out refers to the values at the outlet opening similarly, the other velocity component ( $\mathrm{v}_{\text {out }}$ ) is assumed to be zero. The gradient normal to the outlet line for the following variables $\left(\mathrm{T}_{\text {out }}, \mathrm{k}_{\text {out }}, \varepsilon_{\text {out }}\right)$ is set to zero. Uniform distribution is assumed for $\left(\mathrm{u}_{\mathrm{out}}\right)$ and the other entire variable across the exit area.

\subsection{Wall Boundary Conditions}

Close to the wall region laminar viscosity becomes more significant than turbulent viscosity as a result of the damping effect of the wall. Therefore, the turbulence model Eq. (6) and (7) do not apply to regions close to a solid boundary because turbulence model neglects the laminar viscosity. Fine mesh would be needed near the wall. To avoid this remedy a low Reynolds number model "Wall function" was used. This approach relates surface boundary conditions to points immediately adja- 
cent to a solid wall, which is located in the fully turbulent region ${ }^{[12]}$. The form of wall functions for each of the variables is outlined below.

i- Momentum Flux Near the Wall

Because the walls are impermeable, the normal velocities $\left(u_{n}\right)$ must be zero at the boundaries. The simplest way of imposing tangential velocity $\left(\mathrm{u}_{\mathrm{t}}\right)$, values is to allow either no-slip or free-slip conditions, which are considered currently .

$i i-k$ and $\varepsilon$ Near the Wall

The variation of turbulence kinetic energy $(\mathrm{k})$ in the region near the wall is calculated from the transport equation for $(\mathrm{k})$ with its diffusion to the wall set equal to zero thus:

$$
\frac{\partial \mathrm{k}}{\partial \mathrm{n}}=0
$$

The dissipation rate $(\varepsilon)$ at the wall adjacent node, Eq. (7) is not used and the value of $\varepsilon$ is evaluated as follows:

$\varepsilon=\mathrm{C}_{\mu}^{3 / 4} \mathrm{k}^{3 / 2} / \mathrm{n} \mathrm{k}_{\mathrm{r}}$

Where $=\mathrm{k}_{\mathrm{r}}$ Von Karman constant (0.4178)

iii- Temperature Near the Floor

Adiabatic condition was used,

$\partial \mathrm{T}$

$\overline{\partial n}=0$

\section{The General Form of the Governing PDE'S}

The transport equations for the momentum $(2,3)$, the temperature Eq. (4) and the turbulence scales k and $\varepsilon$ (6) and (7) respectively could be expressed in general form ${ }^{[5,6]}$.

$$
\frac{\partial}{\partial x}(\rho u \varphi)+\frac{\partial}{\partial y}(\rho v \varphi)=\frac{\partial}{\partial x}\left(\Gamma_{\varphi} \frac{\partial \varphi}{\partial x}\right)+\frac{\partial}{\partial y}\left(\Gamma_{\varphi} \frac{\partial \varphi}{\partial y}\right)+S_{\varphi}
$$

The source term $\mathrm{S}_{\varphi}$ may be expressed as a linear expression

$$
\mathrm{S}_{\varphi}=\mathrm{S}_{\mathrm{c}}+\mathrm{S}_{\mathrm{p}} \varphi_{\mathrm{p}}
$$


where $\varphi$ is the dependent variable, $S_{\varphi}$ is source term which has different expressions for different equations, the $\Gamma_{\varphi}$ represents the diffusion coefficient for scalar variables and the $\mu_{\text {eff }}$ for vector variables, (i.e., the velocities) and the $S_{c}$ of Eq. (15) stands for part of $S_{\varphi}, S_{p}$ is the coefficient of $\varphi_{\mathrm{p}}$ Eq. (14) also represents the continuity equation when $\varphi=1$ and $\mathrm{S}_{\varphi}=0$.

\section{Solution of the Discretised Equation}

To obtain the solution of the governing equations, finite volume method where used as a discrietization method to solve PDE numerically by dividing the domain into a number of control volume. Figure 4 illustrates the two-dimensional grid and control volume location. The points of line intersection called grid points and the dotted line shows the control volume faces.

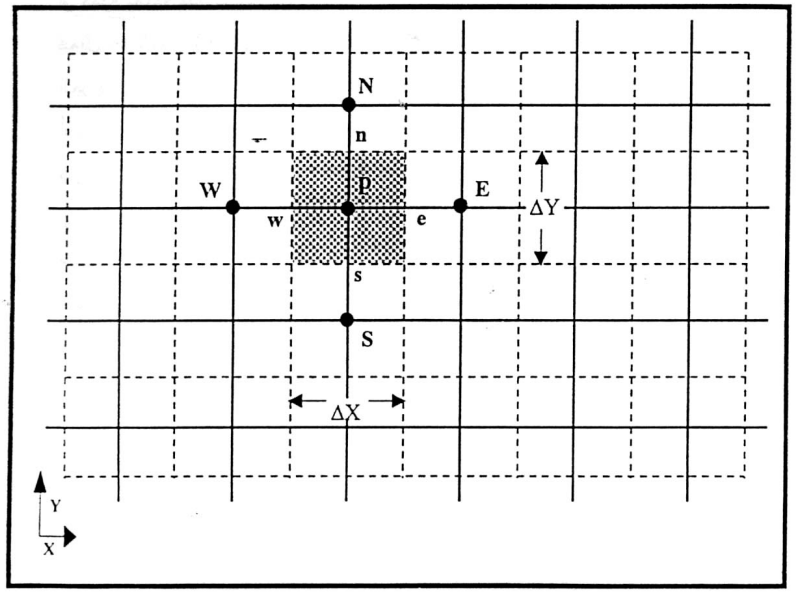

Fig. 4. Two-dimensional staggered grids.

\section{The Staggered Grid}

The staggered variable arrangement where used currently where the pressure is located at the cell center so as the other scalar variable and the velocities at the cell faces. Figure 5 illustrates the staggered location for $\mathrm{u}$ and $\mathrm{v}$. 


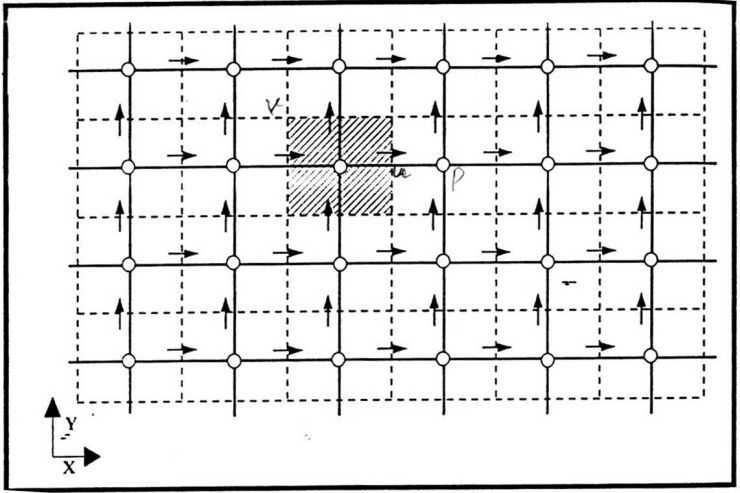

tor $\mathrm{u}$ and $\mathrm{v} . \rightarrow=u ; \mathrm{l}=v ; \bullet=$ other variable

Fig. 5. Staggered locations of $u$ and $v$.

There are several schemes used to find the value of the dependent variable in the desritisation equation such as central differencing, upwind and hybrid schemes. Hybrid is used in this study it employs the central difference formulation when $\left(-2 \leq \mathrm{F}_{\mathrm{e}} / \mathrm{D}_{\mathrm{e}} \leq 2\right)$ and upwind for outside this range.

Semi Implicit Method for Pressure Length Equation (SIMPLE), which links the velocity to the pressure in order to satisfy continuity equation, is used. The aim of this method is correct the guessed value of the pressure and velocity.

\section{Heat Conduction on the Wall}

In this study, the energy balance on volume element that is considered from boundary conditions ABCD (Fig. 6) can be expressed as ${ }^{[13,14]}$ :

$\left(\begin{array}{l}\text { Heat transferred } \\ \text { into or out of the } \\ \text { volume element } \\ \text { from all of its } \\ \text { surfaces }\end{array}\right)+\left(\begin{array}{l}\text { Heat generated } \\ \text { within the } \\ \text { volume element }\end{array}\right)=\left(\begin{array}{l}\text { The change } \\ \text { in the energy } \\ \text { content of } \\ \text { the volume } \\ \text { element }\end{array}\right)$

or

$\Sigma_{\text {All sides }} \mathrm{Q}+\dot{\mathrm{G}}_{\text {element }}=\Delta \mathrm{E}$ element

Because of steady state, $\Delta \mathrm{E}$ element is equal to zero.

Equation (16) can be expressed as: 
$\Sigma_{\text {All sides }} \mathrm{Q}+\dot{\mathrm{G}}_{\text {element }}=0$

In this study, a rectangle car cabin wall in which heat conduction and convection are significant in the $\mathbf{x}$ - and $\mathbf{y}$ - directions is considered. A unit depth of $\Delta \mathbf{z}=\mathbf{1}$ in the $\mathbf{z}$-direction is created. The cabin wall is divided into a rectangular mesh of nodal points spaced $\Delta \mathbf{x}$ or $\Delta \mathbf{y}$ thickness apart in the $\mathbf{x}-$ and $\mathbf{y}$ - thick plane. Figure 7 depicts the general boundary node $(m, n)$ considered.

The control volume boundaries are halfway between the grid points when the node $(m, n)$ is situated on one of the boundaries or in a corner of the conducting domain. Noting that the control volume centered about the general boundary node $(m, n)$ involves heat conduction and convection from four sides :west $\left(\mathrm{q}_{\mathrm{W}}\right)$, east $\left(\mathrm{q}_{\mathrm{E}}\right)$, north $\left(\mathrm{q}_{\mathrm{N}}\right)$ and south $\left(\mathrm{q}_{\mathrm{S}}\right)$ as shown in Fig. 7. The transient finite difference formulation for a general boundary node $(\mathrm{m}, \mathrm{n})$ can be expressed on the basis of Eq. (17) as:

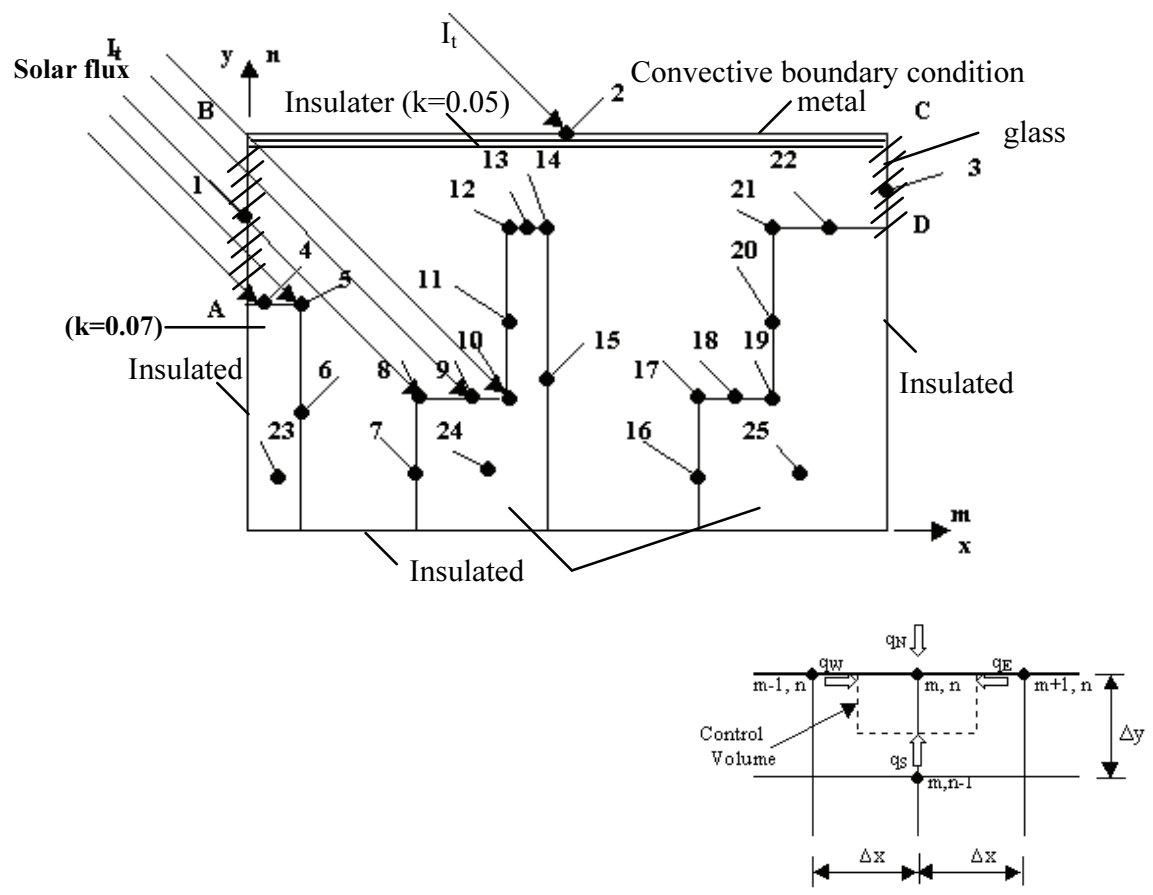

Fig. 6. The grid spread over a 2-D conduction and convection domain (left side), and the control volume associated with a boundary node $(m, n)$ (right side). 


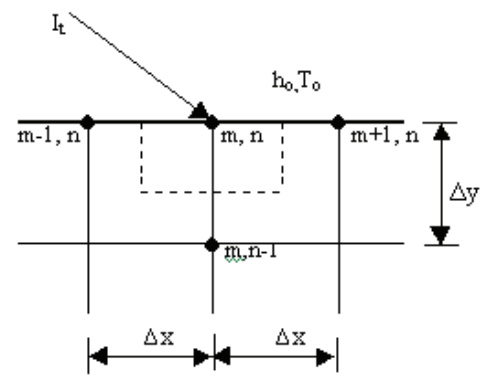

Fig. 7. Schematic for energy balance on the control volume of node (2).

a-For upper car cabin wall from $\mathbf{B}$ to $\mathbf{C}$, this is illustrated below with an example (node2).

$\mathrm{q}_{\mathrm{W}}+\mathrm{q}_{\mathrm{E}}+\mathrm{q}_{\mathrm{N}}+\mathrm{q}_{\mathrm{S}}+\dot{\mathrm{G}}_{\text {element }}=0$

where :

$\mathbf{q w}=$ The heat conductive on the west to the node $(m, n)$

$\mathrm{q}_{\mathrm{w}}=\mathrm{k}_{\mathrm{e}} \cdot \frac{\Delta \mathrm{y}}{2} \cdot \frac{\mathrm{T}_{(\mathrm{m}-1, \mathrm{n})}-\mathrm{T}_{(\mathrm{m}, \mathrm{n})}}{\Delta \mathrm{x}}$

$\mathbf{q}_{\mathbf{E}}=$ The heat conductive on the east to the node (m,n ) at the wall boundary.

$\mathrm{q}_{\mathrm{E}}=\mathrm{k}_{\mathrm{e}} \cdot \frac{\Delta \mathrm{y}}{2} \cdot \frac{\mathrm{T}_{(\mathrm{m}+1, \mathrm{n})}-\mathrm{T}_{(\mathrm{m}, \mathrm{n})}}{\Delta \mathrm{x}}$

$\mathbf{q}_{\mathbf{N}}=$ The heat conductive on the north to the node $(\mathrm{m}, \mathrm{n})$ out of the wall boundary .

$\mathrm{q}_{\mathrm{N}}=\mathrm{h}_{\mathrm{o}} \cdot \Delta \mathrm{x}\left(\mathrm{T}_{\mathrm{o}}-\mathrm{T}_{(\mathrm{m}, \mathrm{n})}\right)$

$\mathbf{q}_{\mathbf{S}}=$ The heat conductive on the south to the node (m,n ).

$\mathrm{q}_{\mathrm{S}}=\mathrm{k}_{\mathrm{e}} \cdot \Delta \mathrm{x} \cdot \frac{\mathrm{T}_{(\mathrm{m}, \mathrm{n}-1)}-\mathrm{T}_{(\mathrm{m}, \mathrm{n})}}{\Delta \mathrm{y}}$

$\mathrm{I}_{\mathrm{t}}=$ Solar radiation

$\dot{\mathrm{G}}_{\text {element }}=\mathrm{I}_{\mathrm{t}} \cdot \Delta \mathrm{x}$

Eq. (18) can be expressed as:

$$
\begin{aligned}
& \mathrm{k}_{\mathrm{e}} \frac{\Delta \mathrm{y}}{2} \cdot \frac{\mathrm{T}_{(\mathrm{m}-1, \mathrm{n})}-\mathrm{T}_{(\mathrm{m}, \mathrm{n})}}{\Delta \mathrm{x}}+\mathrm{k}_{\mathrm{e}} \frac{\Delta \mathrm{y}}{2} \cdot \frac{\mathrm{T}_{(\mathrm{m}+1, \mathrm{n})}-\mathrm{T}_{(\mathrm{m}, \mathrm{n})}}{\Delta \mathrm{x}}+\mathrm{h}_{\mathrm{o}} \cdot \Delta \mathrm{x}\left(\mathrm{T}_{\mathrm{o}}-\mathrm{T}_{(\mathrm{m}, \mathrm{n})}\right) \\
& +\mathrm{k}_{\mathrm{e}} \cdot \Delta \mathrm{x} \cdot \frac{\mathrm{T}_{(\mathrm{m}, \mathrm{n}-1)}-\mathrm{T}_{(\mathrm{m}, \mathrm{n})}}{\Delta \mathrm{y}}+\dot{\mathrm{G}}_{\text {element }}=0
\end{aligned}
$$

Suppose: 
$\mathrm{k}_{\mathrm{e}} \cdot \frac{\Delta \mathrm{y}}{2 \Delta \mathrm{x}}=\mathrm{a}_{\mathrm{w}} \quad$ for west node

$\mathrm{k}_{\mathrm{e}} \cdot \frac{\Delta \mathrm{y}}{2 \Delta \mathrm{x}}=\mathrm{a}_{\mathrm{E}} \quad$ for east node

$\mathrm{h}_{\mathrm{o}} \Delta \mathrm{x}=\mathrm{a}_{\mathrm{N}} \quad$ for north node

$\mathrm{k}_{\mathrm{e}} \cdot \frac{\Delta \mathrm{x}}{2 \Delta \mathrm{y}}=\mathrm{a}_{\mathrm{S}} \quad$ for south node

After substitution of these terms in Eq. (19) the resulting equation is:

$\mathrm{a}_{\mathrm{W}}\left(\mathrm{T}_{(\mathrm{m}-1, \mathrm{n})}-\mathrm{T}_{(\mathrm{m}, \mathrm{n})}\right)+\mathrm{a}_{\mathrm{E}}\left(\mathrm{T}_{(\mathrm{m}+1, \mathrm{n})}-\mathrm{T}_{(\mathrm{m}, \mathrm{n})}\right)+\mathrm{a}_{\mathrm{N}}\left(\mathrm{T}_{\mathrm{o}}-\mathrm{T}_{(\mathrm{m}, \mathrm{n})}\right)+$

$\mathrm{a}_{\mathrm{S}}\left(\mathrm{T}_{(\mathrm{m}, \mathrm{n}-1)}-\mathrm{T}_{(\mathrm{m}, \mathrm{n})}\right)+\dot{\mathrm{G}}_{\text {element }}=0$

Re-arrange

$a_{W} T_{(m-1, n)}-a_{W} T_{(m, n)}+a_{E} T_{(m+1, n)}-a_{E} T_{(m, n)}+a_{N} T_{0}-a_{N} T_{(m, n)}+$

as $\mathrm{T}_{(\mathrm{m}, \mathrm{n}-1)}-\mathrm{as}_{\mathrm{S}} \mathrm{T}_{(\mathrm{m}, \mathrm{n})}+\dot{\mathrm{G}}_{\text {element }}=0$

Suppose:

$$
\mathrm{a}_{\mathrm{W}}+\mathrm{a}_{\mathrm{E}}+\mathrm{a}_{\mathrm{N}}+\mathrm{a}_{\mathrm{S}}=\mathrm{a}
$$

By substituting Equation 22 in Eq. (21), the final equation to calculate the temperature of the boundary node (2) is:

$$
\mathrm{T}_{(\mathrm{m}, \mathrm{n})}=\left(\mathrm{a}_{\mathrm{W}} \mathrm{T}_{(\mathrm{m}-1, \mathrm{n})}+\mathrm{a}_{\mathrm{E}} \mathrm{T}_{(\mathrm{m}+1, \mathrm{n})}+\mathrm{a}_{\mathrm{N}} \mathrm{T}_{\mathrm{o}}+\mathrm{a}_{\mathrm{S}} \mathrm{T}_{(\mathrm{m}, \mathrm{n}-1)}+\dot{\mathrm{G}}_{\text {element }}\right) / \mathrm{a}
$$

b-For cabin wall from A to $\mathbf{B}$ (windshield). This is illustrated below with an example node (1).

$\mathrm{T}_{(\mathrm{m}, \mathrm{n})}=\left(\mathrm{a}_{\mathrm{W}} \mathrm{T}_{\mathrm{o}}+\mathrm{a}_{\mathrm{E}} \mathrm{T}_{(\mathrm{m}+1, \mathrm{n})}+\mathrm{a}_{\mathrm{N}} \mathrm{T}_{(\mathrm{m}, \mathrm{n}+1)}+\mathrm{a}_{\mathrm{S}} \mathrm{T}_{(\mathrm{m}, \mathrm{n}-1)}+\dot{\mathrm{G}}_{\text {element }}\right) / \mathrm{a}$ where :

$$
\begin{aligned}
& \mathrm{a}_{\mathrm{W}}=\mathrm{h}_{\mathrm{O}} \Delta \mathrm{y} \\
& \mathrm{a}_{\mathrm{E}}=\mathrm{k}_{\mathrm{G}} \cdot \frac{\Delta \mathrm{y}}{\Delta \mathrm{x}} \\
& \mathrm{a}_{\mathrm{N}}=\mathrm{a}_{\mathrm{S}}=\mathrm{k}_{\mathrm{G}} \cdot \frac{\Delta \mathrm{x}}{2 \Delta \mathrm{y}} \\
& \mathrm{a}=\mathrm{a}_{\mathrm{W}}+\mathrm{a}_{\mathrm{E}}+\mathrm{a}_{\mathrm{N}}+\mathrm{a}_{\mathrm{S}}
\end{aligned}
$$


c-For cabin wall from $\mathrm{C}$ to $\mathrm{D}$ ( rear window ), the transient energy balance equation is represented by node (3) and is similarly obtained.

d-For the interior surface of the simplified passenger compartment (dash board, front seat, and rear seat), the energy balance equations are represented by nodes as shown in Fig. 8 and are similarly obtained .

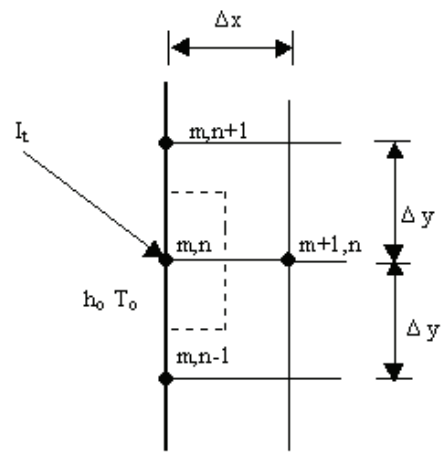

Fig. 8. Schematic for energy balance on the control volume of node (1).

\section{Results and Discussions}

In this section, the computational results for the simplified passenger compartment are discussed. The computational results demonstrate the capability of the present method and also indicate areas for further research. The grid independence was tested in Fig. 9, where the no of the grids was changed in x-direction. The little changed in the center temperature shows the grid independency. The computed velocity vectors are shown at the passenger center plane as shown in Fig. 10. The temperature fields are illustrated in Fig. 11 for the passenger center plane.

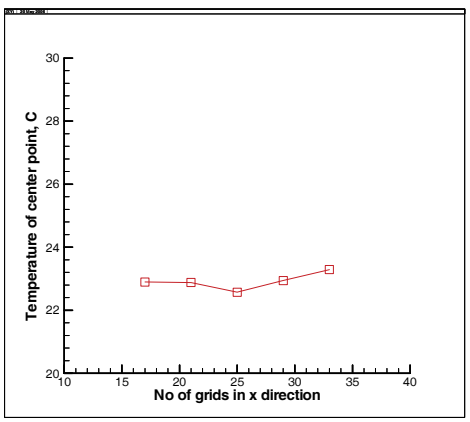

Fig. 9. Grid independence effect. 
During the simulation, the air temperatures at two locations in the passenger compartment were monitored to show the variation in air temperature at locations in the front and rear compartments with the number of inlets which affect the temperature inside car cabin.

\subsection{Velocity Fields}

Figure 10 shows the flow field at the passenger center plane for different numbers of inlets and for the air inlet velocity $U_{\text {in }}=2 \mathrm{~m} / \mathrm{s}$.

For the flow of two inlet (a), three inlet (b) and four inlets (c). Strong turbulent jet from the $\mathrm{A} / \mathrm{C}$ outlets is blocked by the front seat and rear seat and form two re-circulating flow patterns in the front compartment and one re-circulating flow patterns in the rear compartment. The first re-circulating flow in the front compartment is located near the windshield and the second re-circulating flow is located near the front seat leg area. These re-circulating flows are highly effective in mixing the cold air from the $\mathrm{A} / \mathrm{C}$ outlets with the surrounding hot air in the passenger compartment. Some air flow was also delivered to the rear passenger compartment along the roof-line to the exit vent.

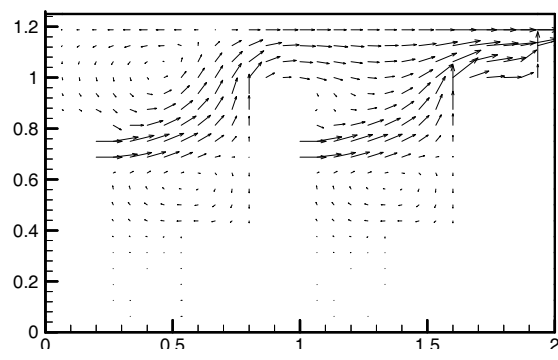

(a)

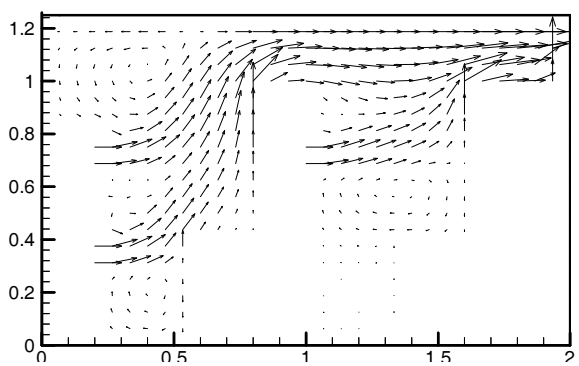

(b)

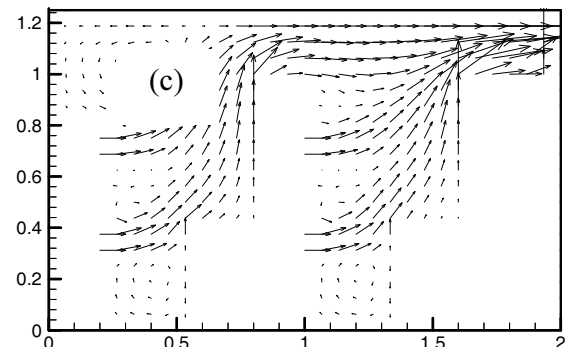

Fig. 10. Flow Field (U\&V Velocity Vectors) for $U_{i n}=2 \mathrm{~m} / \mathrm{s}$, (a-two inlets, b-three inlets, c-four inlets). 


\section{2 Temperature Fields}

Isotherm contours for $U_{\text {in }}=1 \mathrm{~m} / \mathrm{s}$ and $T_{\text {in }}=15^{\circ} \mathrm{C}$ at time $=12 \mathrm{a} . \mathrm{m}$ with different inlets are given in Fig. 11. The temperature distribution in (a) has considerable difference from that for (b) and (c) because the area of hot zones is larger. This is due to the number and location of air conditioning system inlets. There are two main locations of the "hot" areas, being behind the front seats and in the front seat leg areas. These hot areas typically coincide with areas of slow air circulation as in Fig. 11. Increasing the number of air conditioning system inlets leads to decrease the gradient of temperature near interior surfaces, the temperature distribution is more uniform and the area of hot zones is smaller.

\subsection{Comparison between Two Locations Inside car Cabin}

Figure 12 shows the variation in air temperature at location in the front passenger compartment with the number of inlets for different times, $U_{\text {in }}=1 \mathrm{~m} / \mathrm{s}$ and $T_{i n}=15{ }^{\circ} \mathrm{C}$. This figure illustrates a decrease in air temperature at the location in the front passenger compartment when the number of inlets $=3$ for every time. This is due to the third inlet is located in the front compartment.
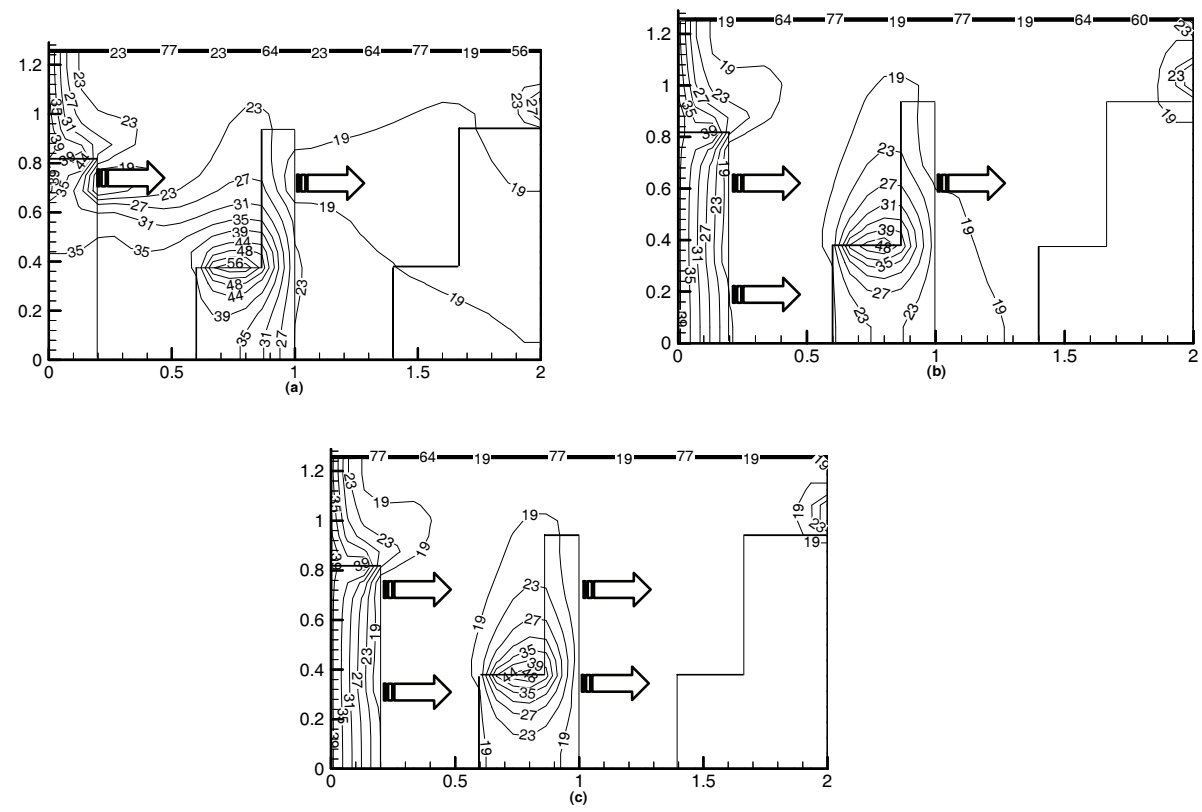

Fig. 11. Isotherm contours for velocity $=1 \mathrm{~m} / \mathrm{s}$, temperature $=15^{\circ} \mathrm{C}$, at time $=12$ a.m. $\left(I_{t}=741 \mathrm{w} / \mathrm{m}^{2}\right)$ and different inlet sizes. 

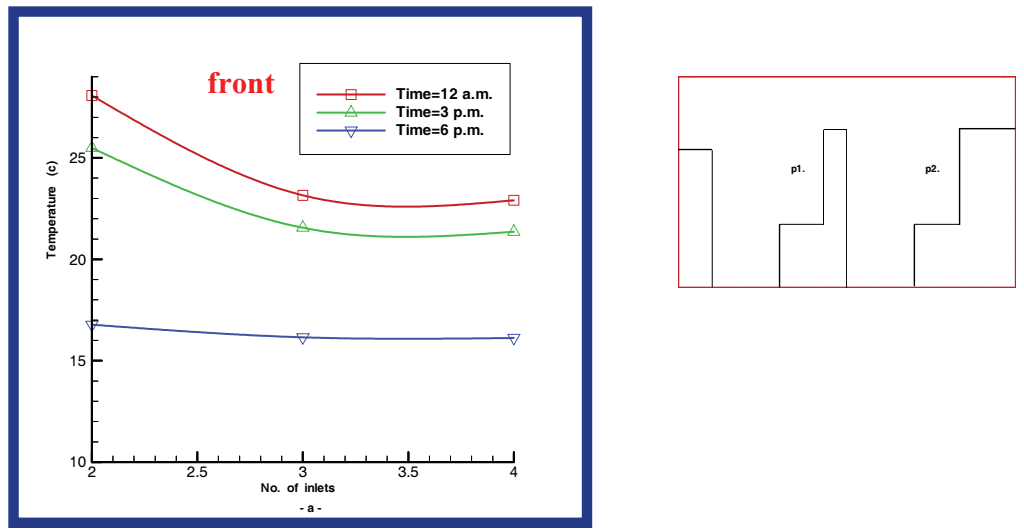

Fig. 12. Variation in air temperature at location(p1) in the front passenger compartment with the number of inlets for $u_{\text {in }}=1 \mathrm{~m} / \mathrm{s}, T_{\text {in }}=15^{\circ} \mathrm{C}$, at time $=12$ a.m. $\left(I_{t}=741 \mathrm{w} / \mathrm{m}^{2}\right), 3$ p.m. $\left(I_{t}=589 \mathrm{w} / \mathrm{m}^{2}\right)$, and 6 p.m. $\left(I_{t}=76 \mathrm{w} / \mathrm{m}^{2}\right)$.

Figure 13 shows lower air temperature at location in the rear passenger compartment for different times when compared with air temperature at the location in the front passenger compartment. This figure illustrates a decrease in air temperatures at the location in the rear passenger compartment when the number of inlets $=4$ for every time. This is because the fourth inlet is located in the rear compartment.
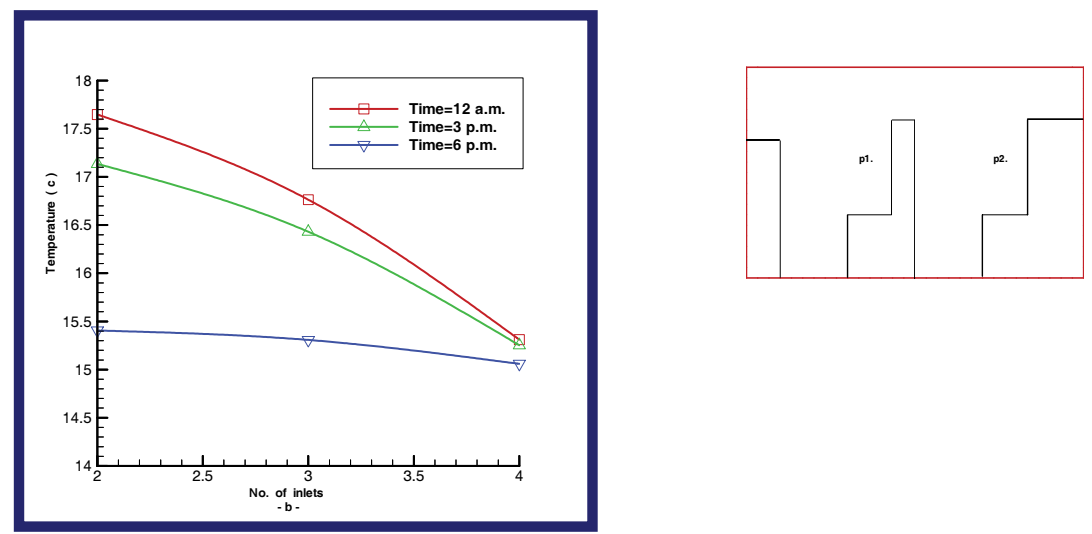

Fig. 13. Variation in air temperature at location (p2) in the rear passenger compartment with the number of inlets for $u_{i n}=1 \mathrm{~m} / \mathrm{s}, T_{i n}=15^{\circ} \mathrm{C}$, at time $=12 \mathrm{a} . \mathrm{m}$. $\left(I_{t}=741 \mathrm{w} / \mathrm{m}^{2}\right), 3 \mathrm{p} . \mathrm{m}$. $\left(I_{t}=589\right.$ $\left.\mathrm{w} / \mathrm{m}^{2}\right)$, and 6 p.m. $\left(I_{t}=76 \mathrm{w} / \mathrm{m}^{2}\right)$. 


\section{Conclusions}

This paper demonstrates the capability of CFD to accurately simulate the air flow within an automobile cabin. The accurate predictions of airflow velocity and temperature distributions are crucial to the success of building a virtual thermal comfort model. The increase of air inlet vents lead to a decrease of the hot zones. It also lead to a lower temperature gradient near the interior surfaces and a uniform temperature distribution.

The results indicate that some of negative effects, for example development of zones of low air circulation can be significantly reduced by improving inlets number. The simulation model takes into account the solar radiation that changes with place, date, and time of day. The (k- $\varepsilon$ ) model can be utilized successfully with turbulent flow to predict the flow and thermal characteristics. The results are used to help trainees better understand the system, and to help engineers design new ventilation systems in the future.

$\mathrm{T}=$ temperature

\section{Notations}

$\mathrm{H}=$ height of the enclosure

$\mathrm{I}_{\mathrm{u}}=$ turbulence intensity

$\mathrm{k}=$ turbulent kinetic energy

$\mathrm{k}_{\text {out }}=$ kinetic energy at outlet

$\mathrm{k}_{\mathrm{r}}=$ Von Karmen constant (0.417)

$\mathrm{I}_{\mathrm{t}}=$ solar radiation

$\mathrm{k}_{\mathrm{e}}=$ Thermal conductivity of the car metal

$\mathrm{k}_{\mathrm{G}}=$ Thermal conductivity of the windshield

$\mathrm{n}=$ normal distance from a wall

$\mathrm{P}=$ pressure

$\mathrm{Q}_{\mathrm{SRF}}=$ conduction through the wall

$\mathrm{Q}_{\mathrm{o}}=$ outward heat flow by convection

$\mathrm{S}_{\varphi}=$ general source term

$\mathrm{u}, \mathrm{v}=$ velocity components $\mathrm{x} \& \mathrm{y}$ direction

$\varepsilon=$ rate of dissipation of kinetic energy

$\mu_{\text {eff }}=$ effective kinematics viscosity

$\Gamma_{\text {eff }}=$ effective diffusion efficient

$\rho=$ fluid density

$\varphi=$ general dependent variable

$\mathrm{A}_{\text {out }}, \mathrm{A}_{\mathrm{in}}=$ cross sectional area of outlet and inlet opening respectively 


\section{$\mathrm{M}, \mathrm{N}=$ number of grid node in $\mathrm{x} \& \mathrm{y}$ direction $\mu_{\mathrm{t}}=$ turbulent viscosity}

\section{References}

[1] Aroussi, A. and Aghil, S., "Characterisation of the Flow Field in a Passenger Car Model " Optical Diagnostics in Engineering, 4(1): 1-15 (2000),

[2] Mann, Martin and Haigis, Matthias, "Numerical Investigation of the Ventilation and Thermal comfort in a Commuter Train", Arsenal Research, Business Area Transport Technologies, Vienna, Austria.

[3] Ambs, Raymond, "Improved Passenger Thermal Comfort Prediction in the Preprototype Phase by Transient Interior CFD Analysis Including Mannequins", SAE Technical Paper Series, 2002-01-0514, U.S.A.

[4] Han, Taeyoung, "Validation of 3-D Passenger Compartment Hot Soak and Cool-Down Analysis for Virtual Thermal Comfort Engineering", SAE Technical Paper Series, 2002-011304, U.S.A.

[5] Alexandrov, Alex, Kudriavtsev, Vladimir and Reggio, Marcelo, "Analysis of Flow Patterns and Heat Transfer in Generic Passenger Car Mini-Environment ", $9^{\text {th }}$ Annual Conference of the CFD Society of Canada, 27-29 May, 2001, Kitchener, Ontario.

[6] Ideriah, F.J.K., "Predition of Turbulent Cavity Flow Driven by Buoyancy and Shear", Journal of Mechanical Engineering Science, 22:287-295 (1984).

[7] Awbi, H.B. and Setrak, A.A., "Numerical Solution of Ventilation Air Jet", The Fifth Int. Symposim on the Use of Computer for Environmental Engineering Related to Building, Bath, England (1986) .

[8] Patankar, S.V., "Numerical Heat Transfer and Fluid Flow", McGraw-Hill, New York (1980).

[9] Pan, W.M. and Spalding, D.B., “A General Computer Program for Two-Dimensional Elliptic Flows", Imperial College, Mech. Eng. Dept. Report HTS 176/2 (Amerded) (1977).

[10] Launder, B.E. and Spalding, D.B., "Mathematical Models of Turbulence", Academic Press, London (1972).

[11] Awbi, H.B. (1998) “Ventilation of Building”, E \& FN spot.

[12] Holman, J.P., "Heat Transfer", McGraw-Hill (1981).

[13] Cengel, Y.A.,"Heat Transfer”, International Edition, McGraw-Hill (1998).

[14] Arpact, V.S., "Conduction Heat Transfer", Addison - Wesley (1966). 


\section{محاكاة CFD لتكييف السيارة}

\section{جلال جليل، و حيدر قاسم علوان}

قسم الثقنية التعلبية - جامعة التقنية - بغد/د - العراق

المستخلص. شملت الدر اسة الحاسوبية الحاليــة محاكــاة الجريانــات الدور انية المضطربة ثنائية الأبعاد داخل حيزكابينة ســيارة المـسافر . وتتضمن الدراسة حل المعادلات التفاضلية الجزئية الأهليلجية و المتنثلة بحفظ الكتلة، و الزخم، ودرجة الحرارة، و الطاقـــة المضطربـــة ومعدل

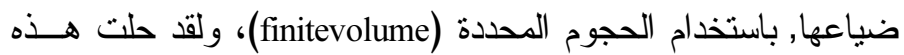

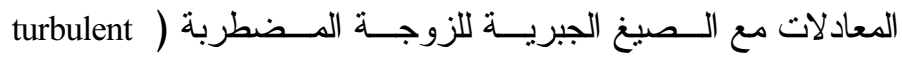

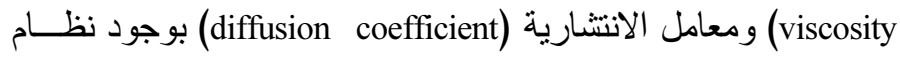
الاضطر اب المسمى (k- (k) )

نم بناء برنامج حاسوبى اهليلجى ثــائي الأبعـاد لحـساب

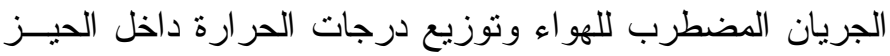
المدروس، ومن خلال متغير ات هندسية مختلفة لتوضيح ناثير ها في حقل الجريان وحقل توزيع درجة الحرارة وتتضمن هذه المتغير ات (نسبة إلى تغيير في عدد و موقع فتحات نظام تكييف الهو اء داخــلــل

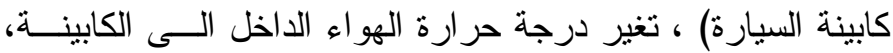

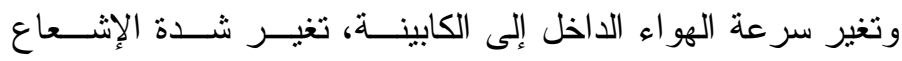

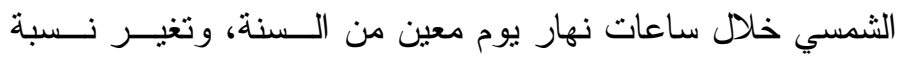

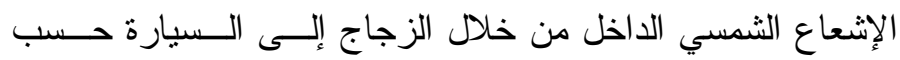
نوعية الزجاج المستخدم في السيارة.

بشكل عام، أوضحت النتائج ظهور بعض التاثير ات السلبية،

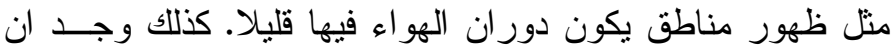
عدد الفتحات المجزةة للهو اء داخل كابينة السيارة يلعب دورا مهما

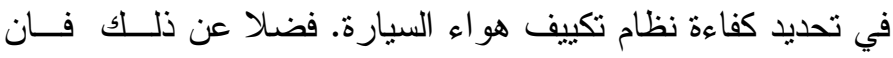




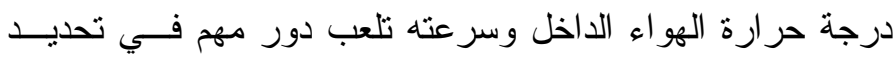
مناخ كابينة السيارة. نستخدم النتائج للمساعدة على فهم أفضل لنظام تكييف هو اء السيارة، وكذلك مساعدة المهندسين على تصميم أنظمة تهوية جديدة في المستقبل. 